\title{
Capital Factors of Rubella Vaccination Behaviour among the Parents in Bangladesh: A PLS-SEM Analysis
}

\author{
Abul Kalam Azad \\ Assistant Professor of Sociology \\ Department of Sociology, Bangladesh University of Professionals (BUP) \\ Mirpur Cantonment, Dhaka-1216, Bangladesh \\ kalamadd@gmail.com
}

\begin{abstract}
This study predicts rubella vaccination behavior of the parents in Bangladesh based on CAPSES model : Human Capital (HC), Material Capital (MC) and Social Capital (SC). A sample size of 72 parents was determined to collect data. The study employed structured questionnaire technique based on 5 point-Likert scale. Then, the study used SmartPLS software (Windows Version-3) to analyze both the measurement and structural models. The study findings lead to this proposition that the higher the CAPSES ranks of the parents, the more likely they will vaccinate their children against MR. On the contrary, the lower the CAPSES rank of the parents, the less likely they will vaccinate their children against MR. Overall, the models have predictive power and relevancein the respective models $\left(R^{2}\right.$ of $\left.R V B 1=0.862\right)$ was found to be more substantial compared to two other CAPSES models $\left(R^{2}\right.$ of $R V B 2=0.240$ and $R^{2}$ of $\left.R V B 3=0.181\right)$.
\end{abstract}

Keyword: CAPSES model, Rubella Vaccination Behaviour, Human Capital, Material Capital, Social Capital

\section{Introduction}

\section{I.1 Background of the Study}

Rubella which is worldwide a major public health concern is as infectious as flu affecting all ages and sexes. Abortion is the most significant aftermath of rubella infection during pregnancy is (Gregg 1941; Miller 1994; Reef 2000; Strauss 1989). If the pregnant woman catches rubella during 1 st trimester (up to week 13 of the pregnancy), there is an $80 \%$ probability that the foetus will also be infected. If she catches rubella during weeks $8-10$ of the pregnancy, there is a 90\% probability that the foetus will have birth defects (Azad 2012 \& 2014). The rubella infection can easily pass to the foetus and cause birth defects, which is known as CRS (Congenital Rubella Syndrome), causing cataracts including other eye defects, deafness, heart abnormalities, a small head, mental retardation, a slower than normal growth rate, and the injuries in the brain, liver and lungs (Azad 2012 \& 2014). In Bangladesh, rubella forms a severe problem affecting all ages and sexes. A national study shows that sera from 609 pregnant women were tested where $86 \%$ were positive in rubella $\mathrm{IgG}$. The prevalence rate was $80 \%$ between 15 and 20 years of age (Nessa 2000). Nessa (2008) in their study on urban and rural Bangladeshi women showed that 71.99 percent of 582 women in the child bearing age was Rubella IgG positive. Rahman (2002) conducted a study on 198 hearingimpaired and 200 without hearing impaired children where rubella antibody was detected as positive in $74 \%$ of the hearing-impaired children and in $18 \%$ of those with normal hearing. 
According to Global Alliance for Vaccination/Immunization (GAVI 2013), rubella incidence in Bangladesh was found among 37 per million individuals followed by 87 per million. WHO (2012) predicts that MR vaccination campaign can significantly reduce the rubella incidence.

According to a report of WHO (2009), all WHO regions either controlled or eliminated MR. In August 2012, the Expanded Programme on Immunization in Bangladesh enlisted rubella vaccine combined with measles to get protected against the disease. Like many countries in Asia, the uptake of MR vaccine was relatively low (WHO 2012; DGHS 2013). The Ministry of Health and Family Welfare of the Government of Bangladesh, to increase the coverage, implemented measles-rubella (MR) vaccination campaign in 2014 among the children aged 9 months to 15 years. During the campaign directed by the GAVI, 86 percent MR vaccination coverage was found among the children of 9 months to 15 years of age (Uddin 2016). However, Azad (2014) found merely $1 \%$ students (whose age exceeded 18 years) of Northern University, Bangladesh to be vaccinated against MMR.

To understand why MR vaccination coverage varied in terms of age, the obvious reason may be the restriction of the free vaccine only up to age 15 years. So, now is the time to conduct research on MR vaccination coverage on the adults of Bangladesh depending on three kinds of capital: material capital (MC), human capital (HC) and social capital (SC) what Oakes \& Rossi (2003) called together CAPSES scale. However, no study has been conducted on explaining rubella vaccination behaviour in Bangladesh based on the CAPSES scale. So, this is the high time to examine the usefulness of CAPSES model to understand the phenomena of rubella vaccination behaviour.

\section{I.2 Research Goal and Objectives}

The main goal of the research is to predict rubella vaccination behaviour among the parents in Bangladesh based on three capital factors of socio-economic status (CAPSES Model). In this regard, the study attempts:

- to understand rubella vaccination behaviour among the study parents;

- to measure the capital factors of the parents in the study areas; and finally

- to examine the effects of capital factors on rubella vaccination behaviour of the study parents.

\subsection{CAPSES Model of Health Behaviour}

No studies have hitherto been conducted on explaining rubella vaccination behaviour among the parents of Bangladesh using CAPSES model. However, many studies have been conducted on explaining the health behaviour based on CAPSES model in global context.

Grossman and Kaestner (1997) found the effect of education as human capital on health status. Parental educational status was also found to be powerful predictor of child health (Desai and Alva 1998; Frost 2005; Thomas 1990, 1991; Mosley and Chen 1984; Chou 2007). Fewer studies reported positive associations between maternal schooling and child health (Shakotko 1981). Oakes and Rossi (2003) suggested material capital to understand health behaviour. (Robert \& House 1996; Spilerman 2000). Many systematic literature reviews (42 papers) showed that health behaviour was significantly associated with social capital (Islam 2006). Kim's (2008) study findings revealed strong relation of physical health with social capital. Wen (2005) conducted a survey on patients diagnosed in 1993 and found 
that mortality was associated with contextual collective efficacy. Recently, Oakes \& Rossi (2003) recommended CAPSES scale for conducting social scientific behavioural researches.

Though there are considerable works on the health issues based on CAPSES model in the global level, there is a gap of research on conducting rubella vaccination behaviour using CAPSES model in Bangladeshi context.

\subsection{Conceptual Framework}

Based on the research objectives and questions as well as considering the gap of the existing literature, the study has designed the following proposed model:

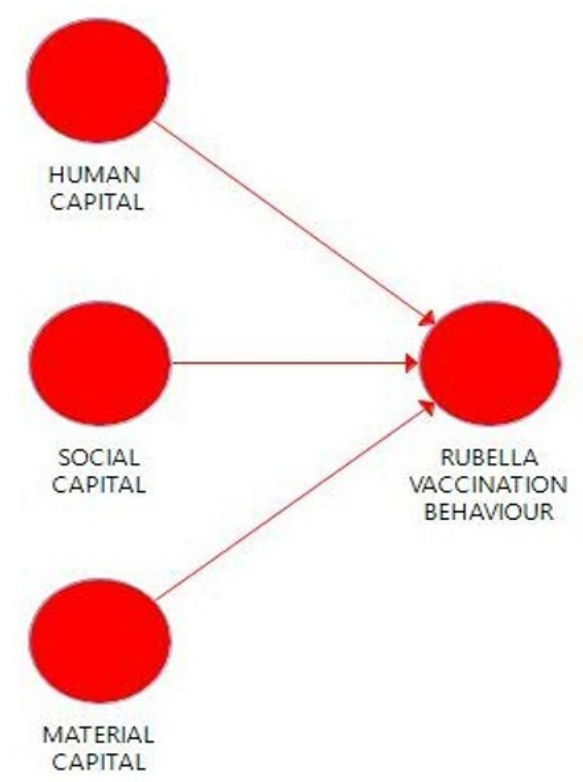

Figure 1 Hypothesised Model

\subsection{Rubella Vaccination Behaviour}

Rubella vaccination behaviour will be measured by offering 12 statements where the respondents will be asked to choose an option under 5 point-Likert scale.

\subsubsection{Human Capital (HC)}

The study defines human capital as individual competency, knowledge, physical abilities (Oakes and Rossi 2003) and academic experience/achievement (Lyons 2003).

\subsubsection{Material Capital (MC)}

In this study, material capital has been defined as the real property (e g. home land), income from earning e g. wages/salaries, tips and other taxable employee pay/selfemployment, income from investment e g. interest payments, dividends and capital gains collected upon the sale of a security and fungible goods e g. gold, company shares, bonds, other precious metals and currencies (Oakes and Rossi 2003).

\subsubsection{Social Capital (SC)}


Social capital includes social network, trustworthiness, status and power (Oakes and Rossi 2003).

\section{Research Methodology}

\subsection{Questionnaire Design}

For collecting data, the study conducted a survey consisting of 4 sections. The first section will cover the respondents' socio-demographics such as gender, age, family size, religion and ethnicity. The other sections of the questionnaire will be: (1) Social Capital (SC); (2) Material Capital (MC); (3) Human Capital (HC); and (4) Rubella Vaccination Behaviour in the study areas. For quantification and scorekeeping, the study will use a 5 point-Likert Scale (e.g., Strongly Disagree=1, Disagree=2, Neutral=3, Disagree=4 and Strongly Agree $=5$ ) for better understanding of the magnitude of the respondents' behaviour.

\subsection{Participants}

The study which is quantitative in nature was carried out on 72 parents of Bangladesh. The sample size was determined considering 12 indicators (6 samples per indicator). Among three categories of the respondents: high awareness, low awareness and no awareness of rubella vaccination, 24 respondents from each category were confirmed for data analysis. However, the respondents were taken from 2 districts- Rajbari (one of the highest vaccine coverage areas) and Munshiganj (one of the lowest vaccine coverage areas)- each containing 36.

\section{II.3 Research Instrument and Statistical Analysis}

After collecting data from the field, to analyse both measurement model and the structural model, the study used Smart PLS software. To evaluate former model, average variance extracted (AVE), Fornell-Larcker criterion and Heterotrait-Monotrait (HTMT) ratio were evaluated (Wong 2013; Hair et al. 2010, 2011 and 2014). Then, the structural model was evaluated through collinearity assessment, standardized path coefficients, T-statistics/P values, coefficient of determination $\left(\mathrm{R}^{2}\right)$, effect size of exogenous constructs on endogenous constructs $\left(\mathrm{f}^{2}\right)$, predictive power/relevance of endogenous construct $\left(\mathrm{Q}^{2}\right)$ and predictive contribution of exogenous to endogenous constructs $\left(\mathrm{q}^{2}\right)$.

\subsection{Ethical Consideration}

Voluntary sharing of the respondents as well as confidentiality of their information were strictly maintained. While interviewing the respondents, force and coercion was avoided and their privacy was safeguarded.

\section{Results of the Study}

\subsection{Characteristics of the Respondents}

Table 1 shows that 50 percent of the respondents were above 16 years and the remaining were upto 16 years. In terms of ethnicity and religion, 100 percent respondents were found Bengali and Muslim. 
Budapest International Research and Critics Institute-Journal (BIRCI-Journal)

Volume I, No 3, October 2018, Page: 56-70 e-ISSN: 2615-3076(Online), p-ISSN: 2615-1715(Print)

www.birci-journal.com emails; birci.journal@gmail.com birci.journal.org@gmail.com

Table 1 Demographic Characteristics of the Respondents

\begin{tabular}{|c|c|c|c|}
\hline \multicolumn{2}{|c|}{ Socio-demographic \& economic Features } & N & \% \\
\hline \multirow{2}{*}{ Age } & Upto 16 Years & 28 & 38.90 \\
\cline { 2 - 4 } & Above 16 Years & 44 & 61.10 \\
\hline \multirow{2}{*}{ Gender } & Female & 20 & 27.80 \\
\cline { 2 - 4 } & Male & 52 & 72.20 \\
\hline \multirow{2}{*}{ Ethnicity } & Bengali & 72 & 100.00 \\
\cline { 2 - 4 } & Others & 0 & 0.00 \\
\hline \multirow{2}{*}{ Religion } & Muslim & 72 & 100.00 \\
\cline { 2 - 4 } & Others & 0 & 0.00 \\
\hline
\end{tabular}
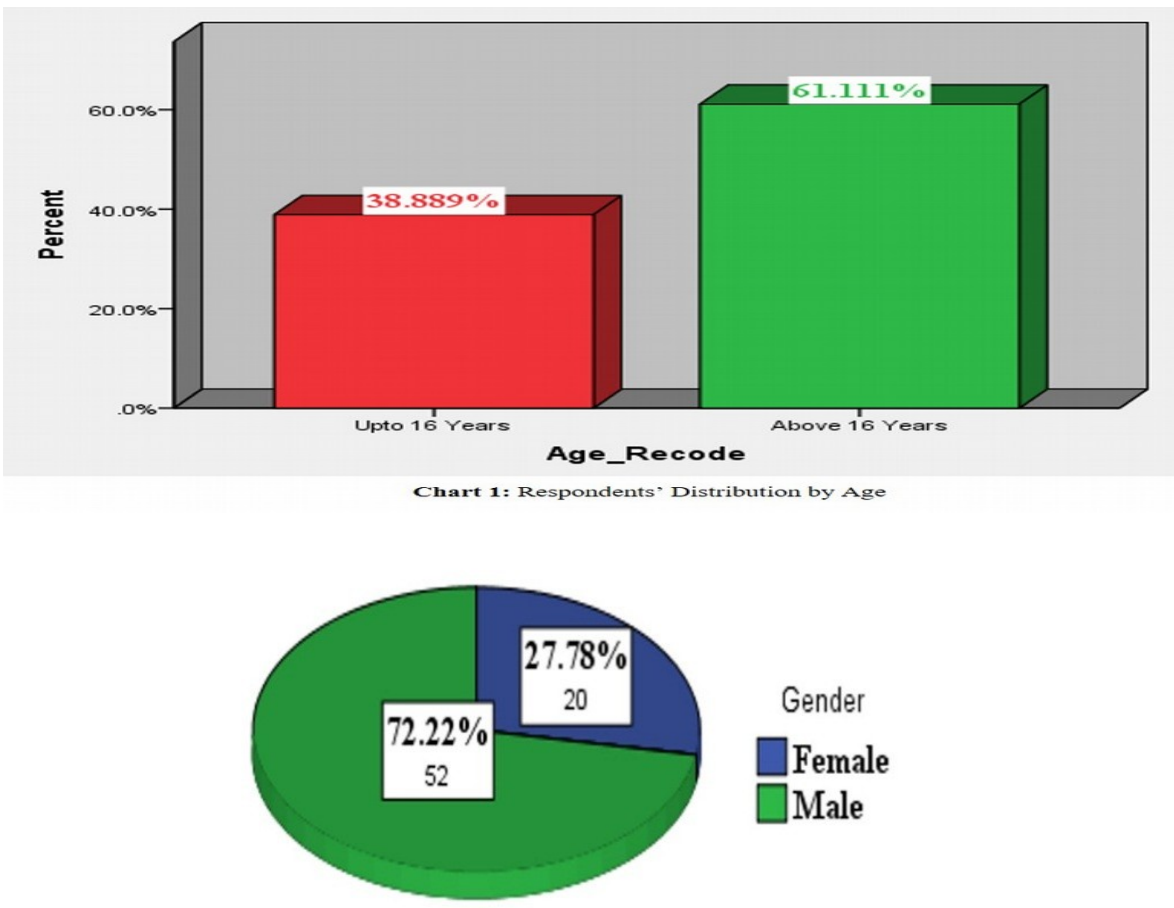

Chart 2: Respondents' Distribution by Gender

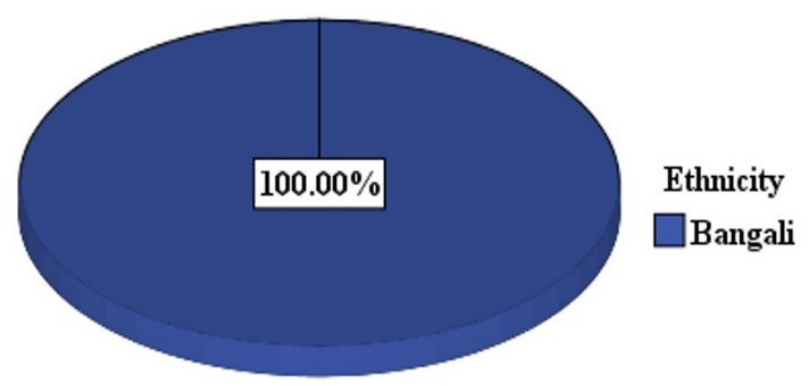

Chart 3: Respondents' Distribution by Ethnicity 


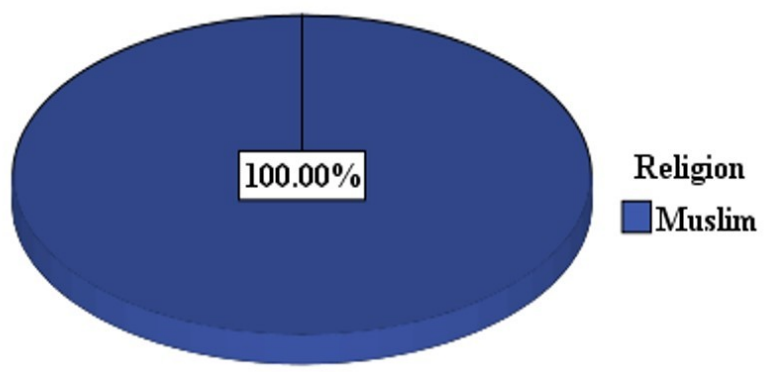

Chart 4: Respondents' Distribution by Religion

\subsection{Respondents' Status of Rubella Vaccination Behaviour}

The statuses of the respondents in terms of rubella vaccination behaviour are evident from the Table 2 below:

Table 2: Respondents' Status of Rubella Vaccination Behaviour

\begin{tabular}{|c|c|c|}
\hline $\begin{array}{c}\text { Respondents'Distribution } \\
\text { by Rubella Vaccination Behaviour }\end{array}$ & $\begin{array}{c}\text { No. of } \\
\text { Respondents }\end{array}$ & $\begin{array}{c}\text { \% of } \\
\text { Respondents }\end{array}$ \\
\hline $\begin{array}{c}\text { High Awareness of Rubella } \\
\text { Vaccination }\end{array}$ & 24 & 33.33 \\
\hline $\begin{array}{c}\text { Low Awareness of Rubella } \\
\text { Vaccination }\end{array}$ & 24 & 33.33 \\
\hline $\begin{array}{c}\text { No Awareness of Rubella } \\
\text { Vaccination }\end{array}$ & 24 & 33.33 \\
\hline Total & 72 & 100 \\
\hline
\end{tabular}

\subsection{Results of Measurement Models}

The combined model (Figure 2) shows that there is a positive effect of Hum Cap, Soc Cap and Mat Cap on RVB1 while the negative effects of those constructs on RVB2 and RVB3 were reported. To compare those models, it is necessary to develop separate models (Model RVB1, Model RVB2 and Model RVB3).

First, Table-3 and Figure-3, 4\&5 show the internal consistency and reliability of data where the values are higher than the threshold value of 0.70 (Wong 2013; J. F. Hair et al. 2010, 2011, 2014, 2016; Nunnally and Bernstein 1994; Urbach and Ahlemann 2010). Convergent validity is also confirmed since the average variance extracted (AVE) of each latent variable is found to be much greater than the acceptable threshold of 0.5 (Wong 2013; J. F. Hair et al. 2010, 2011 and 2014; Nunnally and Bernstein 1994; Urbach and Ahlemann 2010 (Table-4). 
Budapest International Research and Critics Institute-Journal (BIRCI-Journal)

Volume I, No 3, October 2018, Page: 56-70

e-ISSN: 2615-3076(Online), p-ISSN: 2615-1715(Print)

www.birci-journal.com

emails; birci.journal@gmail.com

birci.journal.org@gmail.com
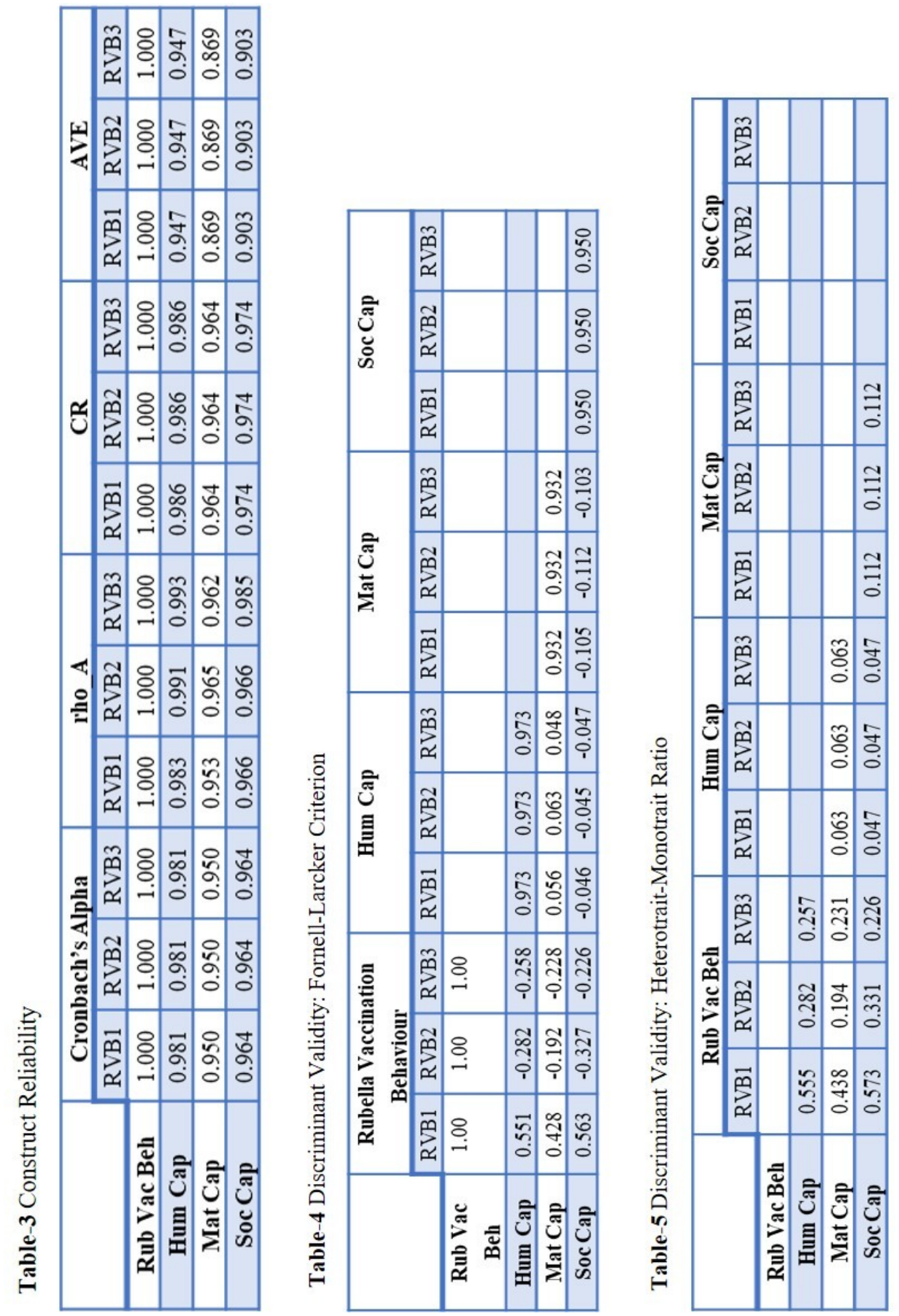
Budapest International Research and Critics Institute-Journal (BIRCI-Journal)

Volume I, No 3, October 2018, Page: 56-70

e-ISSN: 2615-3076(Online), p-ISSN: 2615-1715(Print)

www.birci-journal.com

emails; birci.journal@gmail.com

birci.journal.org@gmail.com

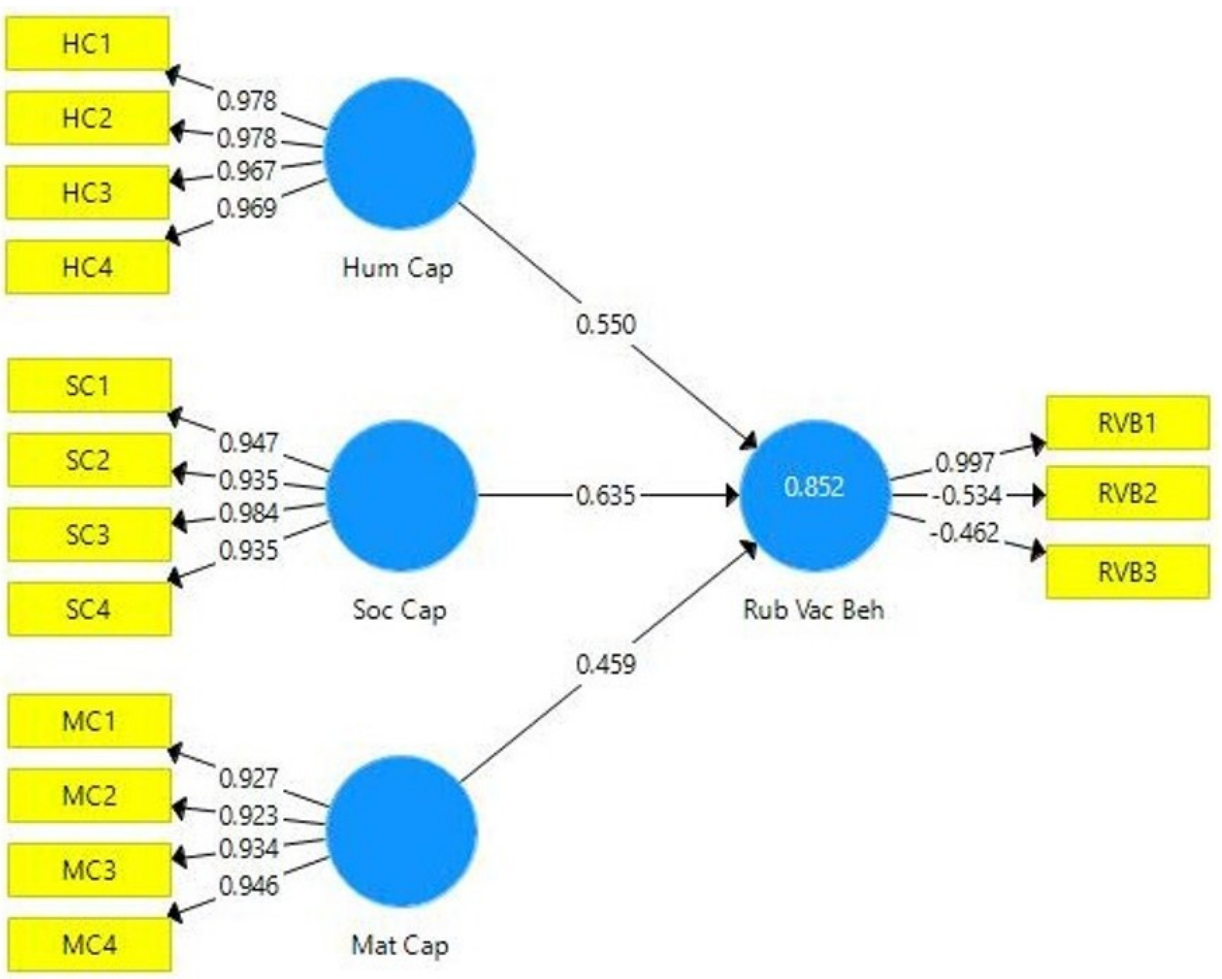

Figure 2 Factor Analysis

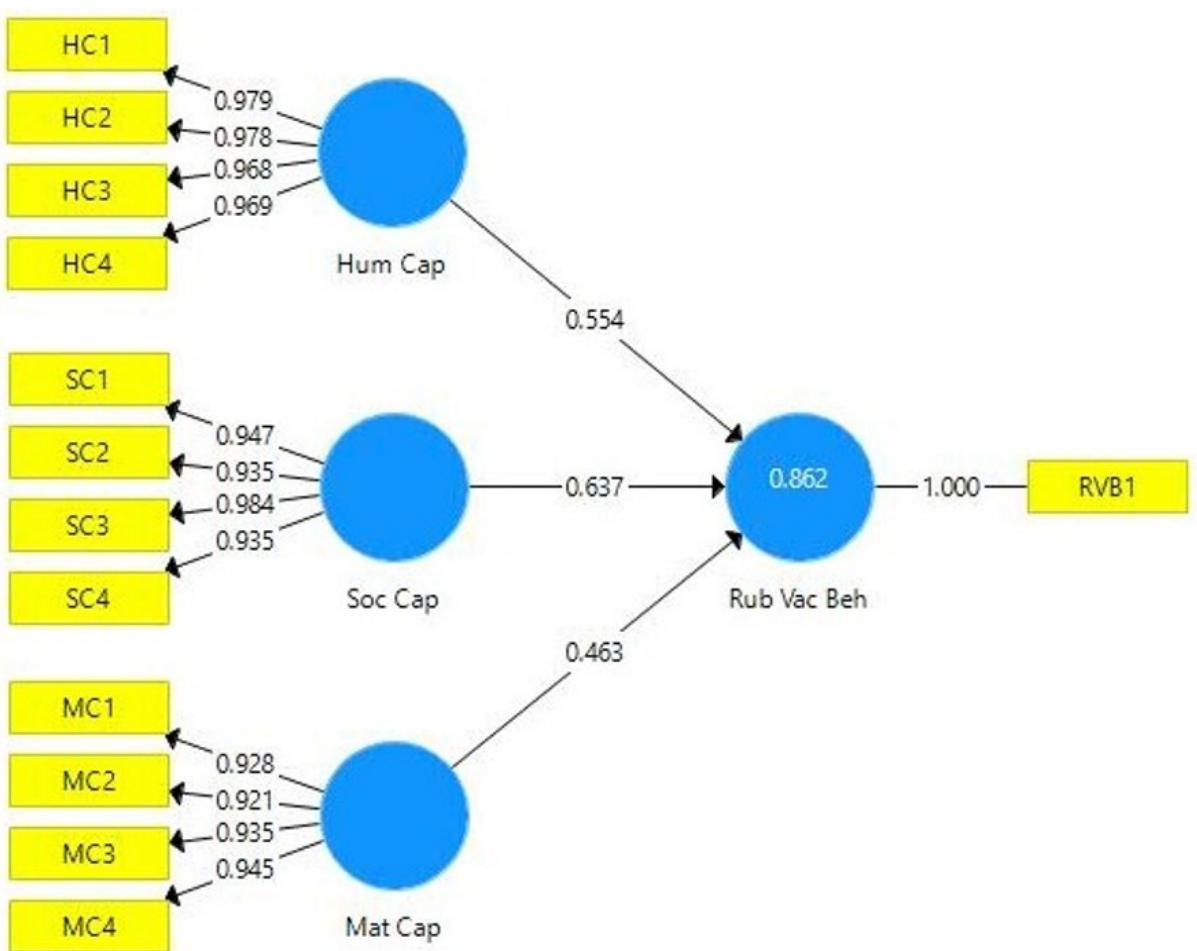

Figure 3 RVB1 Model 
Budapest International Research and Critics Institute-Journal (BIRCI-Journal)

Volume I, No 3, October 2018, Page: 56-70

e-ISSN: 2615-3076(Online), p-ISSN: 2615-1715(Print)

www.birci-journal.com

emails; birci.journal@gmail.com

birci.journal.org@gmail.com

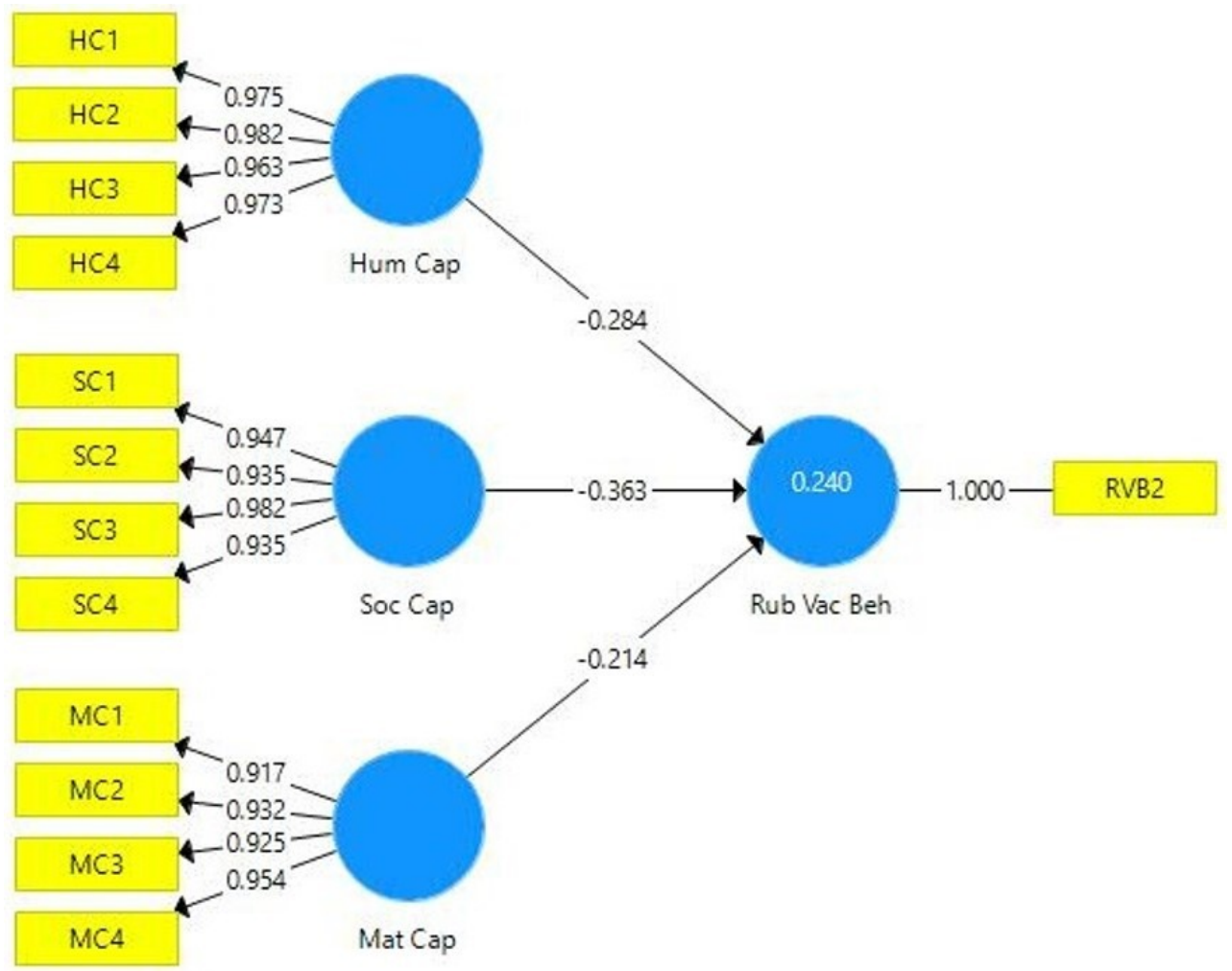

Figure 4 RVB2 Model

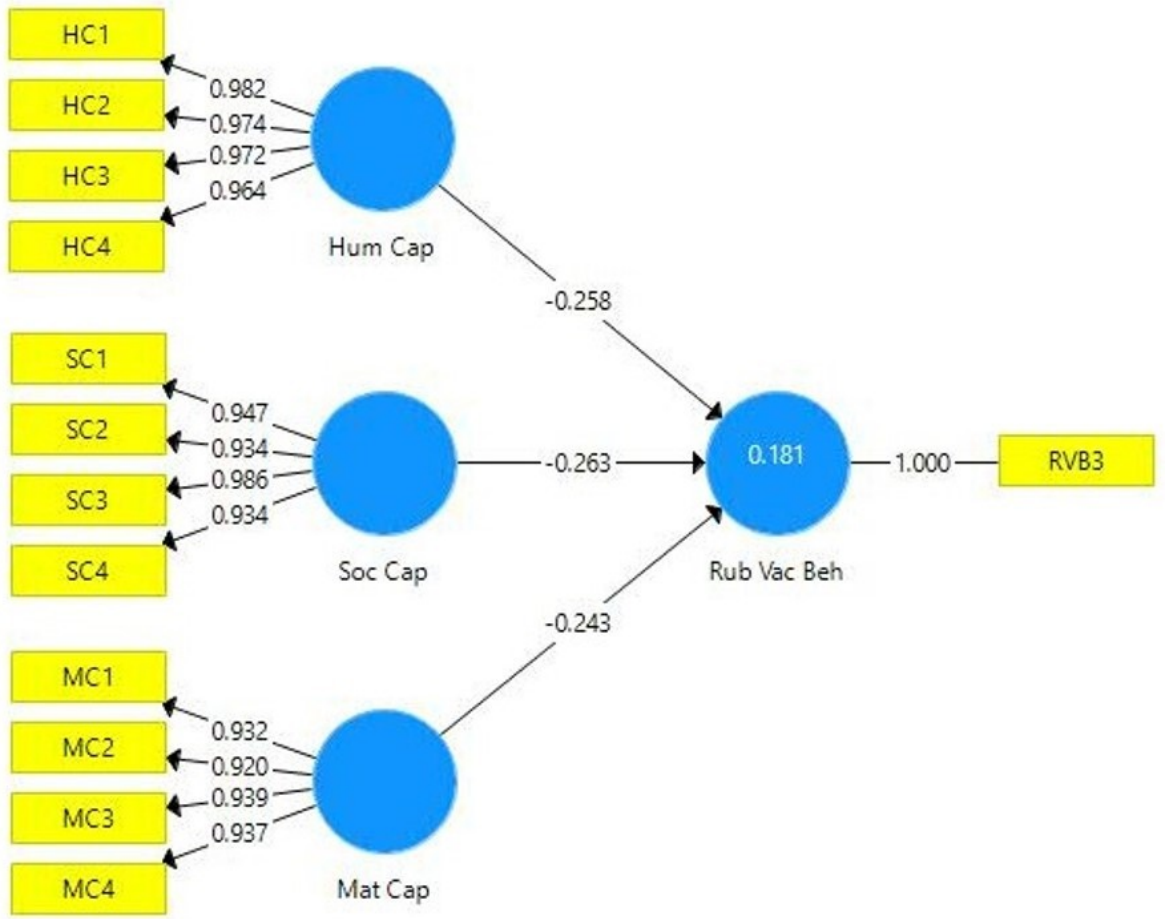

Figure 5 RVB3 Model 
Thirdly, discriminant validity of data are confirmed with Fornell-Larcker criterion and HTMT ratios (Table-5) since the values are found to be much lesser than the threshold value of 0.85 (Clark and Watson 1995; Kline 2011) or 0.90 (Gold, Malhotra, and Segars 2001; Teo et al. 2008).

\subsection{Results of Three Comparative Structural Models}

To evaluate structural model, the study considers collinearity assessment, path coefficients, T-statistics and $\mathrm{P}$ values, coefficients of determination $\left(\mathrm{R}^{2}\right)$, effect size of exogenous constructs on endogenous constructs $\left(f^{2}\right)$, predictive power/relevance of endogenous construct $\left(\mathrm{Q}^{2}\right)$ and predictive contribution of exogenous to endogenous constructs $\left(\mathrm{q}^{2}\right)$. First, in terms of collinearity, no VIF values are found to be greater than 3 (Table-6). So, the latent variables have no problem of multi-collinearity (J. F. Hair et al. 2010, 2011 and 2014; Kock and Lynn 2012; Diamantopoulos and Siguaw 2006).

Thirdly, in terms of path coefficient effect, we find from figure-4a, $4 b$ \& $4 c$ an interesting homogeneous report that Soc Cap has the strongest effect on rubella vaccination behaviour followed by Hum Cap and Mat Cap among the three categories of respondents. So, the hypothesized path relationships between the predictors and Rubella Vaccination Behaviour are found to be statistically significant since the standardized path coefficients are greater than the threshold value of 0.1 (Wong 2013). However, only the CAPSES model of RVB1 show that the three constructs have positive effect on Rubella Vaccination Behaviour. On the contrary, the remaining two CAPSES models show the negative effect of those constructs on Rubella Vaccination Behaviour.

Fourthly, in terms of structural path significance based on bootstrap method taken the large number of subsamples of 5000, T-statistics and $\mathrm{P}$ values using a two-tailed t-test with a significance level of 5\%, we find that except the linkage between Soc Cap and RVB2 (T value of $1.933 \& \mathrm{P}$ value 0.053 ), all the linkages are statistically significant since all the T-statistics are greater than 1.96 and the $\mathrm{P}$ values are smaller than 0.05 (Table- 7).

Fifthly, in terms of coefficient of determination, $\mathrm{R}^{2}$, the endogenous latent variable substantially explain $86.2 \%$ of the variance in RVB1 whereas in cases of two other models, $\mathrm{R}^{2}$ values are not strong $\left(\mathrm{R}^{2}\right.$ for $\mathrm{RVB} 2=0.240 \&$ for $\mathrm{RVB} 3=0.181$ ) (see Wynne W. Chin 1998, 2010). Sixthly, the study finds the effects $\left(f^{2}\right)$ of Hum Cap, Mat Cap and Soc Cap on the 'RVB1' are very strong but weak on 'RVB2' \& 'RVB3' (endogenous latent variable) (Table$8)$.

Seventhly, in addition to evaluate the magnitude of $\mathrm{R}^{2}$ values as criterion of predictive accuracy, the study has also examined Stone-Geisser's Q2 value (Geisser 1975; Stone 1974). That is, to measure the model's predictive power or predictive relevance of endogenous construct 'Rubella Vaccination Behaviour', the value of $\mathrm{Q}^{2}$ has been calculated using Blindfolding method. The study finds the strong predictive power and relevance of endogenous constructs ' $\mathrm{RVB} 1$ ' since the $\mathrm{Q}^{2}$ value is 0.841 that is much greater than the threshold value of 0 (Geisser 1975; Stone 1974). However, the predictive power and relevance of endogenous constructs 'RVB2' and 'RVB3' were found to be comparatively much weaker since the values of $\mathrm{Q}^{2}$ were respectively 0.217 and 0.161 (Table-9). 

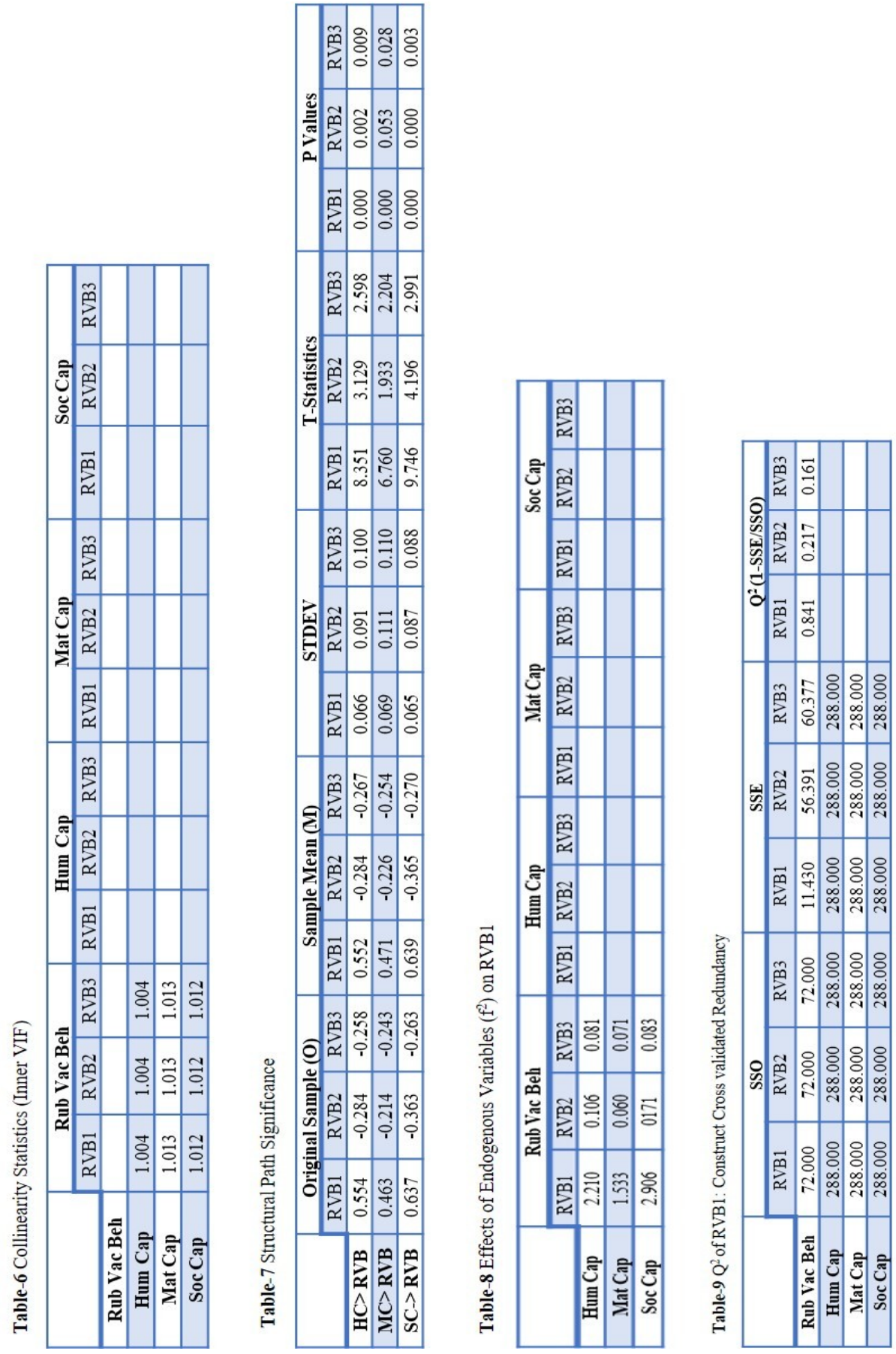

\section{Conclusion and Recommendations}

The study explains and predicts Rubella Vaccination Behaviour among the three categories of parents in Bangladesh based on the CAPSES model: highly aware, low aware and not aware of rubella vaccination. After PLS-SEM analysis of empirical data, the study finds significant effects of human capital, material capital and social capital on the Rubella 
Vaccination Behaviour of the parents in Bangladesh. The study findings lead to this proposition that the higher the CAPSES ranks of the parents, the more likely they will vaccinate their children against rubella. On the contrary, the lower the CAPSES rank of the parents, the less likely they will vaccinate their children against rubella. Overall, the models have predictive power and relevance. In case of CAPSES model of RVB1, the explanatory power $\left(\mathrm{R}^{2}=0.862\right)$ was found to be more substantial compared to two other CAPSES models $\left(\mathrm{R}^{2}\right.$ of $\mathrm{RVB} 2=0.240$ and $\mathrm{R}^{2}$ of $\left.\mathrm{RVB} 3=0.181\right)$. However, the study as an underexplained phenomenon has some recommendations for future researchers to overcome the limitations of the study and to increase the explanatory power of the model. First, the future researchers should conduct rigorous research works using probability sampling technique to make the findings more representative. Finally, sociologists of Bangladesh should contribute to the pitch of Medical Sociology moving from the sociology of rubella vaccination behaviour.

\section{References}

Azad, A. K. 2012. 'Rubella Virus and Congenital Birth Defects in Bangladesh: A Study of Social Determinants'. Journal of Sociology. 4(1):113-126.

Azad, A. K. 2014. 'Measles Mumps and Rubella Vaccination Coverage among the Private University Students of Bangladesh: A Nonfunctional Health Belief Model'. Society \& Change. VIII (1): 27-47.

Chou, S.Y, J.T. Liu, M. Grossman and T.J. Joyce. 2007. 'Parental Education and Child Health: Evidence from A Natural Experiment in Taiwan'. National Bureau of Economic Research. Working Paper, No. 13466, NBER, Cambridge, Mass.

Desai, S. and S. Alva. 1998. 'Maternal Education and Child Health: Is There a Strong Causal Relationship?'. Demography. 35(1):71-81.

Directorate General of Health Services (DGHS). 2013. 'EPI Surveillance Bulletin'. Available from: http://www.dghs.gov.bd/images/docs/EPI/Bulletin\%20for\%20EPI\%20Web\%20Site/2013/EPI \%20Surveillance\%20Bulletin-Issue\%2001-2013.pdf. Accessed 17 Jan 2015.

Frost, M.B, R. Forste and D.W. Haas. 2005. 'Maternal Education and Child Nutritional Status in Bolivia: Finding the Links'. Social Science and Medicine. 60(2):395-407.

GAVI Alliance. 2013. 'Over 700 million children in 49 countries to be protected against measles and rubella'. Available from: http://www.gavialliance.org/library/news/pressreleases/2013/over-700-million-children-in-49-countries-to-be-protected-against-measles-and-rubella/. Accessed 14 July 2013.

Gregg, N. M. 1941. 'Congenital Cataract Following German Measles in the Mother'. Trans Am Ophthalmol Soc. 3:35

Grossman, m. and R. Kaestner. 1997. 'Effects of Education on Health', in J.R. Behrman and N. Stacey (eds.), The Social Benefits of Education. The University of Michigan Press: Ann Arbor.

Hair, Joseph F., William C. Black, Barry J Babin, and Rolph E. Anderson. 2010. Multivariate 
Data Analysis. 7th ed. Prentice Hall: Englewood.

Hair, J. F., W. C. Black, B. J. Babin, and R. E. Anderson. 2011. 'PLS-SEM: Indeed, a Silver Bullet'. The Journal of Marketing Theory and Practice 19 (2): 139-51.

Hair, J. F., M. Sarstedt, L. Hopkins, and V. Kuppelwieser. 2014. 'Partial Least Squares Structural Equation Modeling (PLS-SEM): An Emerging Tool in Business Research'. European Business Review 26 (2).

Hair, Joseph F., G. Tomas M. Hult, Christian Ringle, and Marko Sarstedt. 2016. A Primer on Partial Least Squares Structural Equation Modeling (PLS-SEM). 2nd ed. Thousand Oaks: Sage.

Islam M. K, J. Merlo, I. Kawachi, M. Lindstro, U. G. Gerdtham. 2006. 'Social Capital and Health. Does Egalitarianism Matter? A Literature Review'. Int J Equity Health. Vol. 5. pp. 3. DOI: 10.11 86/1475-9276-5-3.

Kim D, Subramanian S. V., Kawachi I. 2008. 'Social Capital and Physical Health: A Systematic Review of the Literature'. In: Kawachi I., S. V. Subramanian, D. Kim, eds. Social Capital and Health. NY: Springer; pp. 139-90

Lyons, Maureen. 2003. Inside Classrooms: The Teaching and Learning of Mathematics in Social Context. Dublin: Institute of Public Administration.

Miller, L. A., R. E. Hoffman, A. E. Barón, , et. al. 1994. 'Risk Factors for Delayed Immunization against Measles, Mumps, and Rubella in Colorado Two Year Olds'. Pediatrics. 94: 213-19.

Mosley, W. H. and L.C. Chen. 1984. 'An Analytical Framework for the Study of Child Survival in Developing Countries'. Population and Development Review. Vol. 10, pp. 25-45.

Nessa, A., S. Khatun, M. N. Islam, and S. Chowdhury. 2000. 'Bangladesh Medical Research Council bulletin'. 26(3), 75-81.

Nessa, A., M. N. Islam, S. Tabassum, S. U. Munshi, M. Ahmed, and R. Karim. 2008. 'Seroprevalence of Rubella among Urban and Rural Bangladeshi Women Emphasizes the Need for Rubella Vaccination of Pre-pubertal Girls'. Indian Journal of Medical Microbiology. 26 (1): 94.

Oakes, J. M., and P. H. Rossi. 2003. 'The Measurement of SES in Health Research: Current Practice and Steps toward A New Approach'. Social Science \& Medicine. 56: 769-784

Rahman, M.M., A. M. Khan, M. M. Hafiz, F. M. Ronny, S. Ara, S. K. Chowdhury, S. S. Nazir, W. I. Khan. 2002. 'Congenital Hearing Impairment Associated with Rubella: Lessons from Bangladesh'. Southeast Asian Journal Tropical Medicine and Public Health. 33(4):811-7

Reef, S.E., Plotkin, S., Cordero, J.F., Katz, M., Cooper, L., Schwartz, B. et. al. 2000. 'Preparing for Congenital Syndrome Elimination: Summary of the Workshop on Congenital Rubella Syndrome Elimination in the United States'. Clin Infect Dis. 31: 85-95. 
Robert, S., \& J. S. House. 1996. 'SES Differentials in Health by Age and Alternative Indicators of SES'. Journal of Aging and Health. 8:359-388.

Shakotko, R.A., L.N. Edwards and M. Grossman. 1981. 'An Exploration of the Dynamic Relationship between Health and Cognitive Development in Adolescence'. In Van der Gaag, J. and M. Perlman (eds.), 'Contributions to Economic Analysis: Health, Economics, and Health Economics'. North Holland: Amsterdam.

Spilerman, S. 2000. 'Wealth and Stratification Processes'. Annual Review of Sociology. 26:497-524.

Strauss, J. et. al. 1989. 'Serological Survey of Rubella in Yemen in 1985. Journal of Hygiene, Epidemiology, Microbiology and Immunology, 33: 163-167.

Thomas, D., J. Strauss and M.H. Henriques. 1990. 'Child Survival, Height for Age and Household Characteristics in Brazil'. Journal of Developmental Economics. 33:197-234.

Thomas, D., J. Strauss and M.H. Henriques. 1991. 'How Does Mother's Education Affect Child Height?'. Journal of Human Resources. 26(2):183-211.

Uddin MJ, M. Shamsuzzaman, L. Horng, A. Labrique, L. Vasudevan, K. Zeller, et. al. 2016. 'Use of Mobile Phones for Improving Vaccination Coverage among Children Living in Rural Hard-to-Reach Areas and Urban Streets of Bangladesh'. Vaccine. 34(2):276-283.

Wen M, K. A. Cagney, N. A. Christakis. 2005. 'Effect of Specific Aspects of Community Social Environment on the Mortality of Individuals Diagnosed with Serious Illness'. Soc Sci Med. 61:1119-34.

Wong, Ken Kwong-Kay. 2013. 'Partial Least Square Structural Equation Modeling (PLSSEM) Techniques Using SmartPLS'. Marketing Bulletin 24: 1-32.

World Health Organization. 2009. 'Measles vaccines WHO position paper'. Wkly Epidemiol Rec. 84(35):349-360.

World Health Organization. 2011. 'Measles vaccines WHO position paper'. Wkly Epidemiol Rec. 86(29):301-316.

World Health Organization. 2012. 'Global Measles and Rubella Strategic Plan 2012-2020. 2012. http://apps.who.int/iris/bitstream/10665/44855/1/9789241503396 eng.pdf. Accessed 17 $\underline{\text { Jan } 2015}$.

World Health Organization. 2012. 'Bangladesh Introduces New MR and MCV2 Vaccine to Prevent Measles, Rubella \& (Congenital Rubella Syndrome'. EPI Surveillance bulletin. 15(1):1-5. 
APPENDIX A: Questionnaire based on the indicators of exogenous and endogenous constructs

\begin{tabular}{|c|c|c|c|c|c|c|}
\hline \multirow[t]{2}{*}{ SL } & \multirow[b]{2}{*}{ Indicators/Items of the constructs } & \multicolumn{5}{|c|}{5 Points-Likert scale } \\
\hline & & $\begin{array}{l}\text { Strongly } \\
\text { Disagree }\end{array}$ & Disagree & Neutral & Agree & $\begin{array}{l}\text { Strongly } \\
\text { Agree }\end{array}$ \\
\hline 1 & $\begin{array}{l}\text { HC1: I am individually competent to graduate from general subjects. } \\
\text { [INDIVIDAL COMPETENCY] }\end{array}$ & & & & & \\
\hline 2 & HC2: I am physically well to ensure any work/study. [PHYSICAL ABILITY] & & & & & \\
\hline 3 & $\begin{array}{l}\text { HC3: My previous knowledge obtained from both academia and others makes } \\
\text { me confident to graduate from any subject. [KNOWLEDGE] }\end{array}$ & & & & & \\
\hline 4 & $\begin{array}{l}\text { HC4: My previous academic achievement makes me confident to graduate from } \\
\text { any subject. [ACADEMIC ACHIEVEMENT] }\end{array}$ & & & & & \\
\hline 5 & MC1: My household has sufficient home land. [REAL PROPERTY] & & & & & \\
\hline 6 & $\begin{array}{l}\text { MC2: My household has sufficient income from earning e.g., wages/salaries, } \\
\text { tips, and other taxable employee pay, net earnings from self-employment to bear } \\
\text { my educational costs. [NNCOME FROM EARNING TO BEAR COSTS] }\end{array}$ & & & & & \\
\hline 7 & $\begin{array}{l}\text { MC3: My household has income from investment e.g., interest payments, } \\
\text { dividends, capital gains collected upon the sale of a security or other assets, and } \\
\text { any other profit made through an investment vehicle of any kind. } \\
\text { [INCOME FROM INVESTMENT] }\end{array}$ & & & & & \\
\hline 8 & $\begin{array}{l}\text { MC4: My household has other fungible goods like gold/company } \\
\text { shares/bonds/other precious metals/currencies etc. [FUNGIBLE GOODS] }\end{array}$ & & & & & \\
\hline 9 & $\begin{array}{l}\text { SC1: I have a good network with my friends/family/relatives/career planning } \\
\text { counsellors/reference groups/public opinion leaders etc. [SOCIAL NETWORK] }\end{array}$ & & & & & \\
\hline 10 & $\begin{array}{l}\text { SC2: I have a trust on the members of my social network. } \\
\text { [TRUSTWORTHINESS] }\end{array}$ & & & & & \\
\hline 11 & SC3: My parent owns a high status in my society. [STATUS] & & & & & \\
\hline 12 & SC4: My family has domination in my society. [DOMINATION] & & & & & \\
\hline 13 & RVB1: I am highly aware of rubella vaccination & & & & & \\
\hline 14 & RVB2: I am somewhat aware of rubella vaccination & & & & & \\
\hline 15 & RVB3: I am not aware of rubella vaccination & & & & & \\
\hline
\end{tabular}

